\title{
The woollen manufacture industry in the Azores islands (1850-1930)
}

PAULO SILVEIRA E SOUSA, MAFALDA PACHECO

In Portugal, in the second half of the 19th century, small-scale production of textiles and wool was in competition with cotton fabrics, which invaded even the most peripheral rural areas. Industrial production had its own circuits, offering more products at a better price. It flowed to the urban centers and from there, it radiated to the rural areas, feeding a reasonable commerce in villages and small towns, all over the country. However, the domestic industry was often ignored «because its products rarely appeared in the markets». Our aim is to study the forgotten and hidden activity of the production, spinning and weaving of wool, that was, as we will argue, of great importance in the context of rural farms and communities. This paper will focus on the Azores archipelago, an insular region where the weight of the cattle, artisanal production of textiles and agriculture were strong. Domestic production of textiles stayed important trough time, proved its economic efficiency and its linkage with peasant communties. 